\title{
Congenital paroxysmal atrial tachycardia
}

\author{
DOROTHY J. RADFORD, T. IZUKAWA, and R. D. ROWE \\ From the Division of Cardiology, Department of Paediatrics, Hospital for Sick Children, Toronto, Canada
}

\begin{abstract}
Radford, D. J., Izukawa, T., and Rowe, R. D. (1976). Archives of Disease in Childhood, 51, 613. Congenital paroxysmal atrial tachycardia. Ten infants who had paroxysmal atrial tachycardia in utero or at birth are reported. Because of apparent fetal distress, caesarean section was performed in 4 cases and labour was induced in 1. Birthweight was generally large for gestational age. Severe ascites and hydrops at birth were manifestations of cardiac failure. Atrial flutter was recorded in 4 infants and supraventricular tachycardia in 5 . The Wolff-Parkinson-White syndrome became evident later in 2. Digoxin was given to all 10 infants, and cardioversion was required and was effective in 4 . Known recurrences in childhood have occurred in only 1 patient. Congenital atrial tachyarrhythmias may be commoner than generally believed, and fetal electrocardiography may help to avoid unnecessary termination of pregnancy. Blood sugar determinations are important, since neonatal hypoglycaemia was found. Cardioversion should be performed promptly in severely ill infants or if there is no response to digoxin. Care is required to avoid digoxin toxicity.
\end{abstract}

Atrial flutter and paroxysmal supraventricular tachycardia in infancy have been well documented (Hubbard, 1941; Nadas et al., 1952; Apley, Corner, and Gibson, 1955; Moller, Davachi, and Anderson, 1969; Jacobsen et al., 1975) and the greater likelihood of initial attacks during the first few months after birth has been recognized. Such arrhythmias in utero are usually considered rare (Schaffer and Avery, 1971), though many case reports have been published. Wilburne and Mack (1954) and Siderides, Antonius, and Richlan (1957) documented single cases and reviewed published reports, and McDonagh (1968) reported 2 cases from Liverpool. The largest number of cases comes from Sweden (Lundberg, 1963; Herin and Thorén, 1973).

Three recent cases of congenital paroxysmal atrial tachycardia in utero, with resultant problems at birth, prompted us to review our experience of this condition at the Hospital For Sick Children, Toronto. Over the past 18 years 10 cases have been diagnosed in utero or at birth-more than in any other series. Difficulties in diagnosis have resulted from the varied presentations, and recognition appears to be related to awareness of the entity and of its manifestations. The condition may be commoner than generally believed.

Received 19 December 1975.

\section{Clinical information}

The clinical features of the 10 patients are summarized in the Table. The male: female ratio was $1.5: 1$. Birthweight was generally large for gestational age (Fig. 1). Caesarean section was performed in 4 cases and induction of labour in 1, because of presumed fetal distress suggested by fetal tachycardia and irregularity.

Intrauterine tachyarrhythmia or tachycardia at the birth examination, cyanosis, and cardiac failure were the major presenting features. Severe ascites as a manifestation of cardiac failure, and extensive oedema from hydrops fetalis, led to difficulties in diagnosis. Cardiac murmurs developed in 3 infants; they were considered to be innocent ejection murmurs in 2 and to result from a ventricular septal defect in 1 . Supraventricular tachycardia was noted in 5 patients, in 2 of whom the electrocardiogram (ECG) later showed a Wolff-Parkinson-White (WPW) pattern, and 4 patients had the rhythm of atrial flutter (Figs. 2-4). The initial ECG of one patient (Case 1) was not available for review.

Digoxin was given to all patients from 1 week to 6 months in 9 infants, and because of frequent bouts of tachycardia is still given regularly to the other. This last child has WPW syndrome. Digoxin toxicity developed in 3 infants, and was severe enough in the preterm baby (Case 9) to warrant the insertion of a temporary transvenous pacemaker. Diuretic therapy was given and was effective in 4 patients. Additional diphenylhydantoin and propranolol were given to one infant (Case 8) to control frequent bouts of tachycardia. Cardioversion was successful, with outputs as low as $10 \mathrm{~J}$, in all 4 patients in whom it was used. 
Clinical details in 10 cases

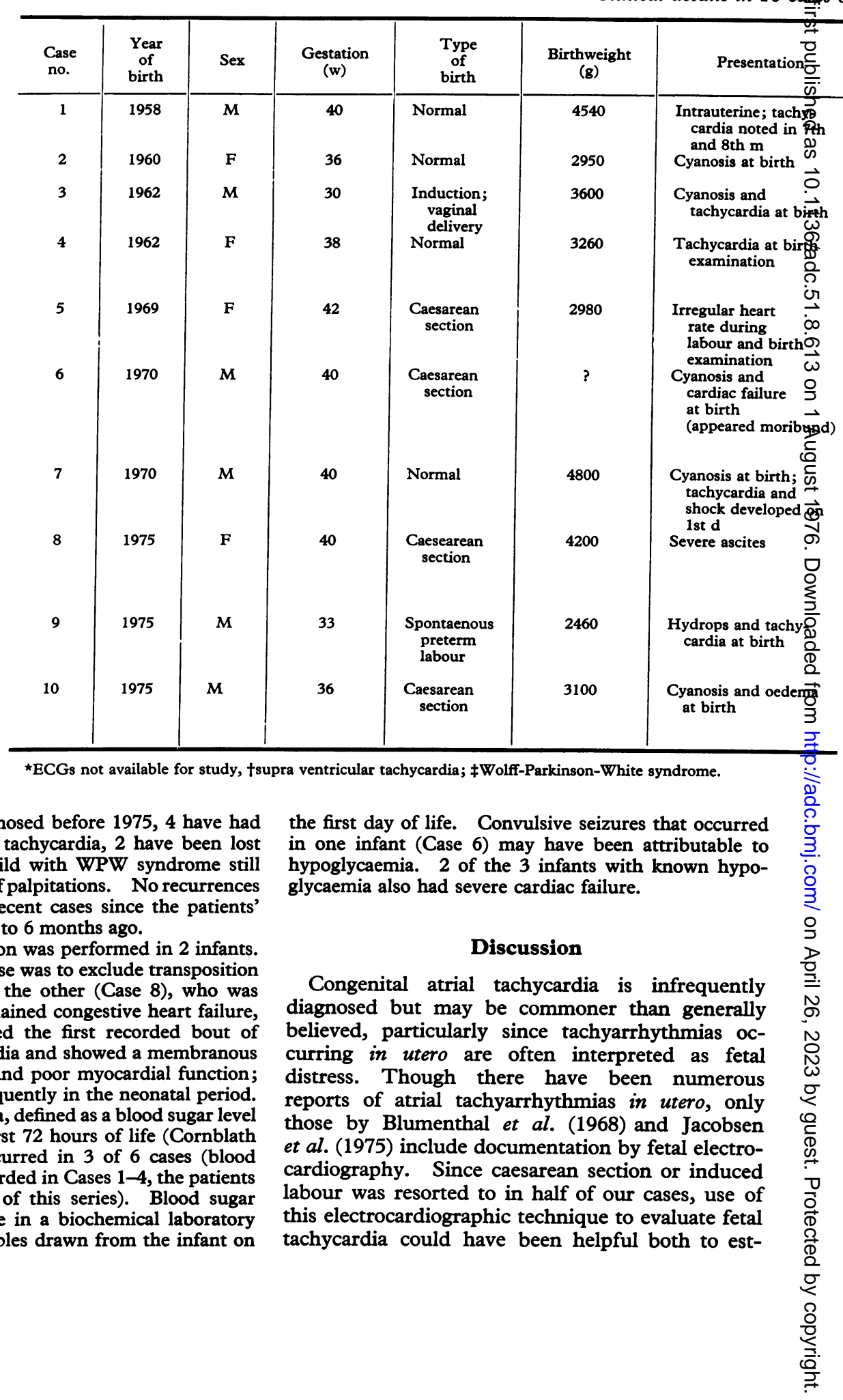

Of the 7 children diagnosed before 1975, 4 have had no recurrent episodes of tachycardia, 2 have been lost to follow-up, and the child with WPW syndrome still has frequent short bouts of palpitations. No recurrences have occurred in the 3 recent cases since the patients' discharge from hospital 3 to 6 months ago.

Intracardiac investigation was performed in 2 infants. In one (Case 6) the purpose was to exclude transposition of the great vessels. In the other (Case 8), who was studied because of unexplained congestive heart failure, the procedure precipitated the first recorded bout of supraventricular tachycardia and showed a membranous ventricular septal defect and poor myocardial function, dysrhythmia recurred frequently in the neonatal period.

Neonatal hypoglycaemia, defined as a blood sugar level $>30 \mathrm{mg} / 100 \mathrm{ml}$ in the first $\mathbf{7 2}$ hours of life (Cornblath and Schwartz, 1966), occurred in 3 of 6 cases (blood sugar values were not recorded in Cases 1-4, the patients seen in the earlier years of this series). Blood sugar determinations were made in a biochemical laboratory on venous or arterial samples drawn from the infant on the first day of life. Convulsive seizures that occurred yypoglycaemia. 2 of the 3 infants with known hypoglycaemia also had severe cardiac failure.

\section{Discussion} curring in utero are often interpreted as fetal distress. Though there have been numerous reports of atrial tachyarrhythmias in utero, only those by Blumenthal et al. (1968) and Jacobsen . (1975) include documentation by fetal electroelectrocardiographic technique to evaluate feta tachycardia could have been helpful both to est- 
ongenital atrial tachycardia

\begin{tabular}{|c|c|c|c|c|}
\hline $\begin{array}{l}\text { Cardiac } \\
\text { failure }\end{array}$ & $\begin{array}{l}\text { Congenital } \\
\text { heart } \\
\text { disease }\end{array}$ & $\begin{array}{l}\text { Rate } \\
\text { and } \\
\text { rhythm }\end{array}$ & Treatment & Comments \\
\hline Yes & No & $236 / \mathrm{min}^{\star}$ & Digoxin; diuretics & $\begin{array}{l}\text { Severe cardiac failure } \\
\text { with oedema and cyanosis; } \\
\text { digoxin toxicity }\end{array}$ \\
\hline Yes & No & $\begin{array}{l}\text { 220/min } \\
\text { SVTt }\end{array}$ & Digoxin & $\begin{array}{l}\text { Digoxin for one week only; } \\
\text { digoxin toxicity }\end{array}$ \\
\hline Yes & No & $\begin{array}{l}200 / \mathrm{min} ; \\
\text { atrial } \\
\text { flutter }\end{array}$ & Digoxin & $\begin{array}{l}\text { Mother had pyelitis; } \\
\text { labour induced because } \\
\text { of fetal tachycardia }\end{array}$ \\
\hline No & No & $\begin{array}{l}\text { 300/min } \\
\text { SVTt }\end{array}$ & Digoxin & $\begin{array}{l}\text { Has WPW } ¥ \text { syndrome and } \\
\text { frequent runs of SVT; } \\
\text { remains on digoxin } \\
\text { therapy }\end{array}$ \\
\hline No & No & $\begin{array}{l}210 / \mathrm{min} ; \\
\text { atrial } \\
\text { flutter } \\
2: 1 \text { block }\end{array}$ & Glucose; digoxin & $\begin{array}{l}\text { Hypoglycaemia; blood } \\
\text { sugar } \\
32 \mathrm{mg} / 100 \mathrm{ml} \text { at } 7 \mathrm{~h}, \\
25 \mathrm{mg} / 100 \mathrm{ml} \text { at } 12 \mathrm{~h}\end{array}$ \\
\hline Yes & No & SVTt & $\begin{array}{l}\text { Glucose; digoxin; } \\
\text { cardioversion }\end{array}$ & $\begin{array}{l}\text { Hypoglycaemia (blood sugar } \\
25 \mathrm{mg} / 100 \mathrm{ml} \text { at } 7 \mathrm{~h} \text {, } \\
\text { convulsive seizures; cardiac } \\
\text { catheterization showed ana- } \\
\text { tomically normal heart, but } \\
\text { SVT developed }\end{array}$ \\
\hline Yes & No & $280 / \mathrm{min}$ & $\begin{array}{l}\text { Cardioversion; } \\
\text { digoxin; glucose }\end{array}$ & $\begin{array}{l}\text { Blood sugar } \\
45 \mathrm{mg} / 100 \mathrm{ml} \text { on } \mathrm{d} 1 \\
38 \mathrm{mg} / 100 \mathrm{ml} \text { on } \mathrm{d} 2\end{array}$ \\
\hline Yes & $\begin{array}{l}\text { Ventricular } \\
\text { septal } \\
\text { defect }\end{array}$ & $\begin{array}{l}\text { 300/min; } \\
\text { SVTt }\end{array}$ & $\begin{array}{l}\text { Digoxin; diuretics; } \\
\text { propranolol; di- } \\
\text { phenylhydantoin; } \\
\text { cardioversion }\end{array}$ & $\begin{array}{l}\text { Blood sugar } 70 \mathrm{mg} / 100 \mathrm{ml} \text { at } 2 \\
\mathrm{~h} \text {; cardiac catherization } \\
\text { showed ventricular septal } \\
\text { defect and poor myocardial } \\
\text { function; SVT recurred }\end{array}$ \\
\hline Yes & No & $\begin{array}{l}240 / \mathrm{min} \\
\text { atrial } \\
\text { flutter }\end{array}$ & Digoxin: diuretics & $\begin{array}{l}\text { Blood sugar } 45 \mathrm{mg} / 100 \mathrm{ml} \text { at } 14 \\
\text { h; digoxin toxicity; had } \\
\text { transvenous pacemaker; has } \\
\text { WPW ECG pattern }\end{array}$ \\
\hline Yes & No & $\begin{array}{l}200 / \mathrm{min} \\
\text { atrial } \\
\text { flutter }\end{array}$ & $\begin{array}{l}\text { Glucose; digoxin; } \\
\text { diuretics; cardio- } \\
\text { version }\end{array}$ & $\begin{array}{l}\text { Hypoglycaemia (blood sugar } \\
28 \mathrm{mg} / 100 \mathrm{ml} \text { at } 3 \mathrm{~h} \text { of age) }\end{array}$ \\
\hline
\end{tabular}

ablish the diagnosis and to monitor the rate and duration of arrhythmia.

Intrauterine cardiac failure occurs with congenital supraventricular arrhythmias, and the relatively large birthweights of our patients appear directly related to fluid retention from heart failure. In previous reviews (Anderson and Adams, 1953; Moller et al., 1959), also, large birthweights for gestational age were noted. One of our cases presented as hydrops fetalis, a manifestation described in single case reports by Silber and Durnin (1969) and van der Horst (1970). In another of our patients (Case 7), ascites was the major presentation and led to broader investigation, including abdominal paracentesis, before the complete clinical picture could be established. In several infants associated cyanosis raised a suspicion of other neonatal disturbances.

Hypoglycaemia occurred in 3 of our patients, and low blood sugar levels in another, an incidence of more than $50 \%$ in those in whom blood sugar was measured. Transient symptomatic neonatal hypoglycaemia, whose reported incidence is $1 \cdot 3-2 \cdot 9$ per 1000 births, is usually found in infants of low birthweight for their period of gestation, and the pathogenesis is thought to be linked with intrauterine undernutrition (Cornblath and Schwartz 1966). A relation between cardiac failure and neonatal hypoglycaemia has been documented by Reid et al. (1971), and 2 of our 3 patients with known hypoglycaemia had severe cardiac failure. (In fact $\mathbf{8}$ were considered to be in cardiac failure, but the lack of glucose values in all patients precludes definition of a relation in this series.) There appear to be no previous reports of hypoglycaemia in association with congenital paroxysmal tachycardia.

Although digoxin is the treatment of choice for 


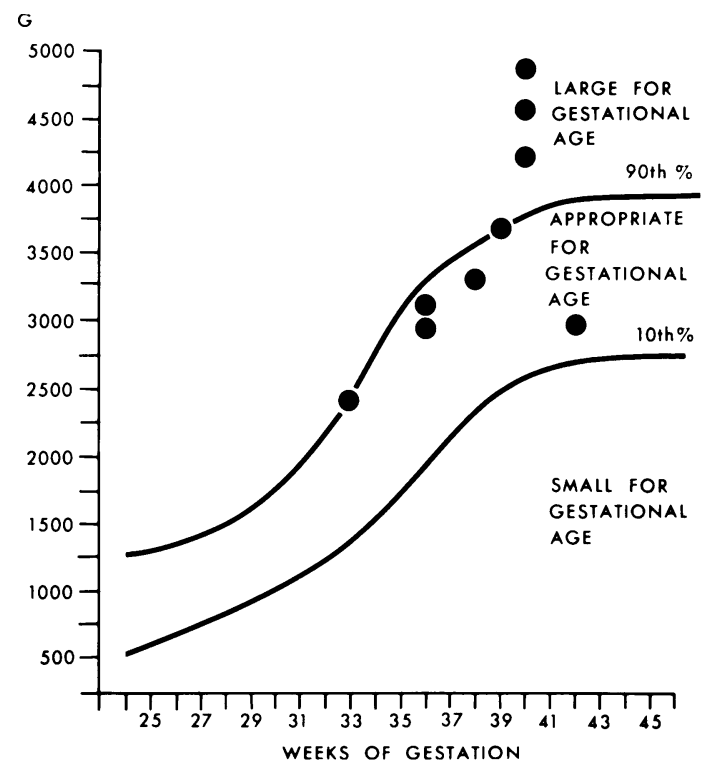

FIG. 1.-Birthweight plotted against gestational age of 9 infants, on graph formulated by Battaglia and Lubchenco (1967). This showis a tendency for large birthweight. (Birthweight of the 10th infant was not recorded; see Case 6 in Table.)

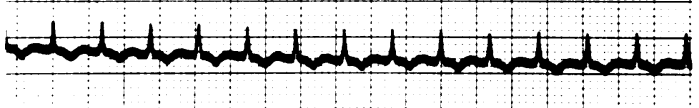

FIG. 2.-ECG lead II of Case 2 shows supraventricular tachycardia at rate of $200 / \mathrm{min}$.

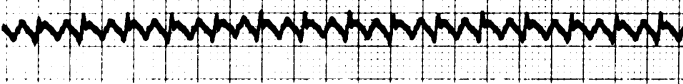 \\ (a)}

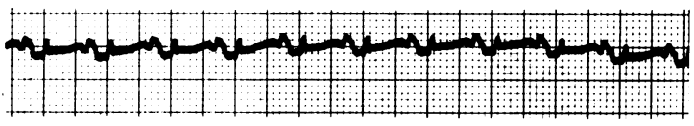

(b)

FIG. 4.-ECG lead II of Case 10. (a) Shows atrial flutter with $2: 1$ block; (b) after cardioversion to normal sinus rhythm.

atrial arrhythmias in infancy (Nadas et al., 1952), Moller et al. (1969) noted in their review on atrial flutter that response to this drug occurred in only half of the cases, the dysrhythmia continuing in some infants for up to $2 \frac{1}{2}$ years. They also recorded some fatalities. In all of our patients rhythm reverted to normal early and none died. We attribute this to the prompt use of cardioversion in the latter part of the series. This has become our first line of therapy if an infant appears seriously ill; in other cases digoxin is given initially and, if there is no response, cardioversion is then performed. In our experience only low energy outputs are necessary. Similar success in infants has been reported by Hassenrück, Chojnacki, and Barber (1965) and Barclay and Barr (1972). Digoxin toxicity in 3 of our patients probably reflects calculation

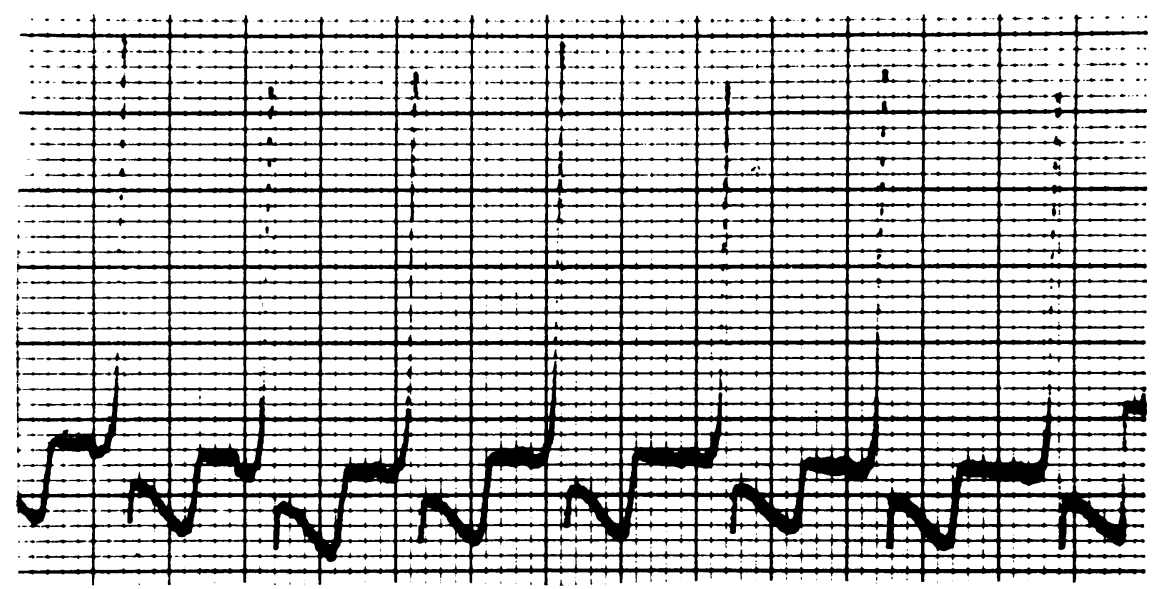

FIG. 3.-ECG lead $V_{1}$ of Case 4 at age 2 days, shows typical pattern of Wolff-Parkinson-White syndrome. 
of the dosage on the infant's large oedematous bodyweight. Recurrent bouts of supraventricular tachycardia continued in one infant (Case 8) after the administration of digoxin, two attempts at cardioversion, and a trial with diphenylhydantoin, and control was finally achieved with the combination of digoxin and propranolol.

Congenital atrial tachyarrhythmias have been reported in cases of congenital heart disease, the lesions including atrial septal defect, Ebstein's anomaly, transposition of the great vessels, coarctation of the aorta, isolated dextrocardia, and endocardial fibroelastosis (Siderides et al., 1957). Only one of our patients had a congenital cardiac lesion; this was a ventricular septal defect, not previously reported in this condition.

The aetiology is not known, but later ECG of 2 of our patients showed a WPW pattern. The long-term prognosis for congenital atrial tachycardia appears to be good, except when there is coexistent congenital heart defect or atrial fibrillation (Moller et al., 1969). In our series recurrence is known to have occurred in only the one patient with the WPW syndrome. A higher incidence of recurrent attacks has been reported when onset of the condition occurs after the first year of life (Nadas et al., 1952; Keith, Rowe, and Vlad, 1967) and in patients with the WPW syndrome (Andersen et al., 1973).

\section{REFERENCES}

Andersen, E. D., Jacobsen, J. R., Sandøe, E., Videbœk, J., and Wennevold, A. (1973). Paroxysmal tachycardia in infancy and childhood. I. Paroxysmal supraventricular tachycardia. Acta Paediatrica Scandinavica, 62, 341.

Andersen, R. C., and Adams, F. H. (1953). Congenital paroxysmal tachycardia. Report of a case and review of the literature. Fournal of Pediatrics, 43, 668.

Apley, J., Corner, B. D., and Gibson, T. C. (1955). Paroxysmal tachycardia in infancy. Archives of Disease in Childhood, 30, 517.

Barclay, R. P. C., and Barr, D. G. D. (1972). Direct current cardioversion in a case of congenital atrial flutter. Archives of Disease in Childhood, 47, 833.

Battaglia, F. C., and Lubchenco, L. O. (1967). A practical classification of newborn infants by weight and gestational age. Fournal of Pediatrics, 71, 159.

Blumenthal, S., Jacobs, J. C., Steer, C. M., and Williamson, S. W. (1968). Congenital atrial flutter: report of a case documented by intra-uterine electrocardiogram. Pediatrics, 41, 659.

Cornblath, M., and Schwartz, R. (1966). Disorders of Carbohydrate Metabolism in Infancy, p. 82. Saunders, Philadelphia.

Hassenrück, A., Chojnacki, I. B., and Barker, H. J. (1965). Cardioversion of auricular flutter in a newborn infant. American fournal of Cardiology, 15, 726.

Herin, P., and Thorén, C. (1973). Congenital arrhythmias with supraventricular tachycardia in the perinatal period. Acta Obstetricia et Gynecologica Scandinavica, 52, 381.

Hubbard, J. P. (1941). Paroxysmal tachycardia and its treatment in young infants. American fournal of Diseases of Children, 61, 687 .

Jacobsen, J. R., Andersen, E. D., Sandøe, E., Videbœk, J., and Wennevold, A. (1975). Chronic supraventricular tachycardia in infancy and childhood. Acta Paediatrica Scandinavica, 64, 597.
Keith, J. D., Rowe, R. D., and Vlad, P. (1967). Heart Disease in Infancy and Childhood, 2nd ed., p. 1062. Macmillan, New York.

Lundberg, A. (1963). Paroxysmal tachycardia in infancy. A clinical and experimental study. Acta Paediatrica Scandinavica, 52, Suppl. 143.

McDonagh, B. J. (1968). Congenital atrial flutter. Archives of Disease in Childhood, 43, 731 .

Moller, J. H., Davachi, F., and Anderson, R. C. (1969). Atrial flutter in infancy. Fournal of Pediatrics, 75, 643.

Nadas, A. S., Daeschner, C. W., Roth, A., and Blumenthal, S. L. (1952). Paroxysmal tachycardia in infants and children. Study of 41 cases. Pediatrics, 9, 167.

Reid, M. McC., Reilly, B. J., Murdock, A. I., and Swyer, P. R. (1971). Cardiomegaly in association with neonatal hypoglycaemia. Acta Paediatrica Scandinavica, 60, 295.

Schaffer, A. J., and Avery, M. E. (1971). Diseases of the Newborn, 3rd ed., p. 237. Saunders, Philadelphia and London.

Siderides, L. E., Antonius, N. A., and Richlan, A. (1957). Unusual auricular flutter in newborn infant. Fournal of Pediatrics, 51, 435.

Silber, D. L., and Durnin, R. E. (1969). Intrauterine atrial tachycardia associated with massive edema in a newborn. American Fournal of Diseases of Children, 117, 722.

van der Horst, R. L. (1970). Congenital atrial flutter and cardiac failure presenting as hydrops foetalis at birth. South African Medical fournal, 44, 1037.

Wilburne, M., and Mack, E. G. (1954). Paroxysmal tachycardia in the newborn with onset in utero. Fournal of the American Medical Association, 154, 1337.

Correspondence to Dr. D. Radford, Division of Cardiology, Hospital for Sick Children, 555 University Avenue, Toronto, Canada M5G 1 X8.

\section{Addendum}

Since submitting this paper we have seen 2 further cases.

Case 11. Spontaneous preterm labour occurred at 34 weeks' gestation and fetal tachycardia $>200 / \mathrm{min}$ was detected. A male infant was delivered vaginally, birthweight $3460 \mathrm{~g}$ (>97th centile for gestation). He was cyanosed and grossly oedematous at birth. ECG showed atrial flutter. Echocardiogram, viral titres, and thyroid function tests were normal. Blood sugar was $53 \mathrm{mg} / 100 \mathrm{ml}$ at 18 hours. Cardiac failure and tachycardia were controlled quickly with digitalization. On the 4th day the serum digoxin level was $>5 \mathrm{ng} / \mathrm{ml}$ (normal $<2 \cdot 5$ ) and therefore the drug was stopped, and he remains well.

Case 12. 6 weeks before delivery the mother of this girl developed polyhydramnios. At 37 weeks' gestation spontaneous labour started during which a rapid and irregular heart rate was noted. The infant weighed $3390 \mathrm{~g}$ at birth and was in cardiac failure with generalized oedema and ascites. ECG showed atrial flutter. Blood sugar level was $41 \mathrm{mg} / 100 \mathrm{ml}$ at 3 hours of age. Digoxin was started but cardioversion and quinidine were also required for control in the neonatal period. There have been no subsequent recurrences. 